\title{
THE ANALYSIS OF THE TOURISM PROMOTION SYSTEM IN POLAND AS COMPARED TO THE FRENCH MODEL OF "INSTITUTIONAL PROMOTION"
}

\author{
MIROSŁAW MARCZAK \\ Gdańsk School of Banking, POLAND \\ e-mail: miromilan@wp.pl
}

KEYWORDS

ABSTRACT tourism promotion system, institutional promotion, National Tourism Organization, effectiveness of promotion

This article analyses the Polish tourism promotion system as compared to the French solution, which is a model solution according to the author, one that is based on the so-called "institutional promotion". A decision has been made to compare these systems of tourism promotion for two reasons. Firstly, both systems of tourism promotion are based on a significant number of institutions that function both on the local level and on the regional level, ones that cooperate at the same time with the National Tourism Organization. Secondly, in spite of the potentially evident similarities, the analyzed systems of promotion exhibit many divergent features, which, consequently has an effect on the size and structure of the incoming tourist traffic. The following research thesis has been assumed: an effective tourism promotion system must be based on the mutual cooperation of all the institutions that are involved in promotional activities. This concerns those entities that function on all the levels of administration (local, regional and national).

\section{Introduction}

The main purpose of this article is to compare the tourism promotion systems in Poland and France. In spite of the seemingly substantial similarities (concerning in particular the use of the existing administrative structure for promotion: three levels of government administration), the analysed promotion systems demonstrate numerous distinct properties decisive as regards their effectiveness, and, consequently, size and structure of the incoming tourist traffic. The article 
demonstrates that it is not the number of the entities and institutions responsible for promotion that decides about the effectiveness of the promotion system; it is their mutual cooperation (not competition!) based, among others, on the efficiently functioning tourist information system, managerial personnel that is professionally prepared to attend to tourists and to undertake joint initiatives, also those relating to the public and private partnerships and aimed at an increase of the level of the tourist- and investment attraction.

\section{Tourism promotion system in Poland}

Two institutions, i.e. the National Tourism Organization (NTO) and the National Tourism Administration (NTA) are the main entities responsible for the functioning of the Polish tourism. The Polish Tourism Organization performs NTO's function in Poland, while the Ministry of Sports and Tourism performs NTA's function.

The National Tourism Organization (NTO) is a national tourism policy entity of the public and private (government and local-government) nature. It can be financed both with public and private funds. The most important objectives of the NTO include the following:

- formulation and implementation of marketing campaigns,

- international promotional activities,

- managing the promotional activities of foreign departments,

- drawing up and production of promotional publications,

- acting as a "link of cooperation" between the government and the private sector. ${ }^{1}$

The National Tourism Administration (NTA) is a national tourism policy entity of the governmental nature financed with public funds. The most important objectives of this type institutions include the following:

- coordination of the tourism development,

- formulation of the national tourism policy,

- international affairs in the area of tourism,

- tourist consultancy,

- crisis management,

- tourism investments,

- "filling in the gaps" left by the private sector.

The above mentioned types of institutions realize joint tasks as well. These include the following:

- licensing tourism activities,

- taking care of appropriate legal regulations,

- organization of trainings within the framework of the so-called tourism education,

- development of the tourism product,

${ }^{1}$ J. Borzyszkowski, Polityka turystyczna państwa, Politechnika Koszalińska, Koszalin 2005, p. 29. 
- tourism market research,

- tourism statistics. $^{2}$

The above presented objectives of both types of institutions explicitly indicate the fact that the National Tourism Organization, whose objectives are realized by the Polish Tourism Organization, is the main entity responsible for the promotion of Poland abroad. However, according to the principles of the Act on Polish Tourism Organization ${ }^{3}$, regional tourism organizations and local tourism organizations are supposed to be responsible for tourism promotion on the state's territory.

\section{Functioning of the Polish Tourism Oryanization}

The draft of the national tourism organization act in Poland was prepared in the year 1998. In the same year, it was passed to the first parliamentary reading. After some minor amendments, on 25 June 1999, the Polish Tourism Organization Act was finally adopted. The Act came into effect on 1 January 2000. From the perspective of the NTO's history, it needs to be mentioned that its formulation in Poland was significantly delayed. Out of all the national tourism organizations in Europe, the Polish institution was the last one to be established. Previously, NTOs were established not only in states with highly developed tourism economy (e.g. Italy, France) but also in former communist states (including the Czech Republic, Slovakia and Hungary). ${ }^{4}$

The objectives and targets defined in the Act are achieved by the Polish Tourism Organization in particular through the following:

- preparation and publication of promotional materials, organization of national stands at tourism fairs, exhibitions, shows, congresses and seminars, and also popularization of knowledge about Poland as a country that is attractive to tourists, in particular through the Polish Tourist Information Centres,

- carrying out statistical and marketing analyses, expert opinions and prognostic studies in the area of tourism,

- initiating and offering organizational support to activities undertaken by competent government administration authorities and state organizational entities, local-government entities and organizations for entrepreneurs in the area of tourism for tourist infrastructure development and modernization as regards an improvement of the quality of tourist services, development of tourism products and their promotion,

- ensuring functioning and development of the Polish tourist information system at home and abroad, as well as support for work aimed at the creation and development of the booking system of tourist services,

- expressing opinions in relation to those plans, strategic from the perspective of the interests of Poland that are prepared by the minister for tourism, local-government entities and organizations for entrepreneurs in the area of tourism,

\footnotetext{
2 J. Borzyszkowski, op.cit., p. 31.

3 Act of 25 June 1999 concerning Polish Tourism Organization, “Journal of Laws” No. 62, Item. 689.

4 J. Borzyszkowski, op.cit. p. 49.
} 
- initiation and issuing of opinions concerning plans and long-term programmes of promotion, development and modernization of the tourist infrastructure, especially as regards an improvement of the quality of tourist services and development of tourism products,

- cooperation with regional and local tourism organizations. ${ }^{5}$

To a great extent, the tourism image of Poland abroad is created by Polish tourist information centres. They are established in countries which are very important and prospective for the tourism influx into Poland. At present, the Polish Tourism Organization possesses 14 such centres, out of which 12 are located in Europe, one in New York, USA, and one in Tokyo, Japan. The European centres cover 17 countries with their activities, out of which 14 are European Union member states. The offices of Polish Tourist Information Centres are currently located in Austria, Belgium, France, Spain, the Netherlands, Germany, Russia, Sweden, Hungary, Great Britain, Italy and Ukraine. Also, in the year 2010, the Polish Tourism Organization conducted intensive promotional and informational activities in India and China. ${ }^{6}$

The Polish tourist information centres are formed in order to realize the statutory objectives of the Polish Tourism Organization in the areas of their operations. However, their presence on a given market facilitates the collection of information concerning trips from a given country, an analysis of data obtained from various sources. It allows one to directly and permanently contact mass media and the representatives of the industry, as well as to contact those consumers who are planning a visit to Poland and are asking for information and materials. The information and knowledge collected by the centres, impossible to be obtained without their work, forms the basis for the creation of plans and strategies of the Polish Tourism Organization.

Owing to the cooperation with foreign posts of the Ministry of Foreign Affairs, the longstanding presence on the market, good knowledge of the realities as well as the culture and traditions of a given country, the personnel of foreign centres of the Polish Tourism Organization can predict in an exceptionally effective manner tendencies and trends in tourism and, following this, they form an image of Poland. This allows a coherent and effective promotion of Poland both in Europe and all over the world. Consequently, Poland is becoming an increasingly popular destination for tourists from all over the world.

The organization of study trips for Polish and foreign journalists and educational trips for tour operators constitutes an important activity area of the Polish Tourism Organization. The purpose of those trips is presenting the most valuable sites in Poland in an appealing and convincing manner. Numerous articles about Poland that appear in reputed consumer and professional journals crop up later as a result of these trips. Educational trips for tour operators bear fruit in the form of new offers of trips to Poland in individual countries.

\footnotetext{
${ }^{5}$ Ordinance by the Minister of Economy dated 28 April 2006 on granting the statute for the Polish Tourism Organization, amended with the Ordinance by the Minister of Economy dated 1 June 2007 on granting the statute for the Polish Tourism Organization.

${ }^{6}$ The analysis of foreign markets 2010 based on reports from Polish Tourist Information Centres + China and India, Warsaw 2011.
} 
The preparation of promotional publications about Poland is an equally important part of the activities of the Polish Tourism Organization. The brochures of the Polish Tourism Organization are published in 12 languages. Their subject matter covers all the issues of interest to the potential tourist, from UNESCO monuments, the historic values of individual towns and regions, active business and spa tourism, to Polish traditions and cuisine. Publications by the Polish Tourism Organization, owing to their characteristic layout and interesting topics, are recognizable and considered to be one of the best in the world. Additionally, the Polish Tourism Organization offers support to the publishing activities of regions by subsidizing the most interesting brochures issued by regional tourist organizations.

The operations of the Convention Bureau of Poland, responsible for the promotion of Poland as an attractive destination for the organization of meetings and business events, are dynamically developing. This is the first contact for those seeking the information on their prospective business partners and conference facilities, or for whomever is planning to organize a congress or a corporate event in Poland.

Within the framework of promotional activities at home, the Polish Tourism Organization closely cooperates with local governments, institutions of culture, tourism industry as well as regional and local tourism organizations. They constitute a forum for cooperation between local governments, professional industry organizations and economic entities that operate in tourism. Their objectives are: the coordination of promotional activities in the province or commune and the district, the creation of an attractive image of the region and the stimulation of the creation and development of tourism products. At present, all Polish provinces have their regional tourism organizations established as well as several to a dozen or so local tourism organizations. Owing to the cooperation with those entities, it is possible to combine invention and promotional activities on the local level with the promotional strategy and funds of the Polish Tourism Organization.

Numerous events that promote regions, towns and individual local tourism products among national and foreign tourists constitute the effect of this cooperation. Stands at fairs, competitions, seminars and conferences are also among these jointly organized events. All of them aim at the popularization of Poland, and they also contribute to an increased awareness of tourism: its positive influence on the state's economy, such as, for example, an increase in the number of workplaces.

The Polish Tourism Organization also manages the Internet tourist information system. In the future, this system aims at becoming a national database of the information about all those entities that operate in tourism industry (including hotels, accommodation facilities, restaurants, conference facilities, travel agencies, tour operators, organizations and tourist associations etc.).

\section{Operations of regional tourism organizations}

As mentioned previously, regional tourism organizations constitute the forum of cooperation between the local government on the provincial level and professional industry organizations as well as economic entities that operate in tourism in the area of the promotion of the area covered by the activities of such organizations as an attractive tourist region at home and abroad. As a rule, 
regional tourism organizations function in the form of associations. At present, there are 16 regional tourism organizations that are active in Poland. ${ }^{7}$

Based on Art. 4.3. of the Polish Tourism Organization Act (as amended), the requirements of the Polish Tourism Organization as well as the guidelines related to the creation of a three-level system of tourism promotion in Poland (that has been under construction since the year 2000), the most important objectives of regional tourism organizations include the following:

- coordination of promotional activities in the province,

- formation of a regional tourist information system: to provide comprehensive information about the province based on local tourist information centres and an inclusion of the tourist information system in national solutions,

- promotion of the region's tourist values at home and abroad,

- stimulation of the creation and development of the tourism product in the region (ensuring a high quality of the tourism product, one which is able to compete internationally),

- initiation, provision of opinions and support of the plans of tourist infrastructure development and modernization,

- offering inspiration and aid with the formation of Local Tourism Organizations in the region,

- training of personnel for the needs of tourism,

- research and marketing analyzes in the area of tourism. ${ }^{8}$

\section{Functioning of local tourism organizations}

Local tourism organizations, similarly to regional tourism organizations, constitute the forum of cooperation between the local government (especially the local government on the district and communal levels) and the local tourism industry (being widely understood due to the heterogenic nature of tourism economy) with regard to the tourism promotion of the area covered by the operations of this organization and, in particular, the creation (forming, promotion and development) of local tourism products. Local tourism organizations function in the form of associations. Currently, there are 125 local tourism organizations in Poland.

The most important objectives of local tourism organizations include the following:

- integration of the local community, mainly local government entities and tourism industry,

- creation of the tourism product (formation, development and promotion) in connection with local tourist attractions,

- collection and updating of information about tourist attractions and products,

- maintaining and running local tourist information centres.

7 The Lower Silesian Tourism Organization, Kuyavia-Pomerania Tourism Organization, Lublin Regional Tourism Organization, Lubusz Regional Tourism Organization, Little Poland Tourism Organization, Mazovia Regional Tourism Organization, Opole Regional Tourism Organization, Podkarpacie Regional Tourism Organization, Podlasie Regional Tourism Organization, Pomerania Regional Tourism Organization, Regional Tourism Organization of the Łódź Province, Regional Tourism Organization of the Świętokrzyskie Province, Silesian Tourism Organization, Warmia-Mazovia Regional Tourism Organization, Great Poland Tourism Organization, West Pomeranian Regional Tourism Organization.

${ }^{8}$ The Polish Tourism Organization, www.pot.gov.pl. 
To sum up, the tourism promotion system in Poland is of an institutional nature. Apart from the institutions appointed with the aim of the realization of objectives directly associated with the promotion of tourism (including the Polish Tourism Organization, regional tourism organizations, local tourism organizations), many other institutions (including local governments and those representatives of tourism industry that are members of regional and local tourist organizations) undertake initiatives of this type. This causes a significant dispersion of promotional activities. Therefore, the view maintained by A. Szwichtenberg, namely, that the tourism promotion must possess a professional character, seems to be correct. ${ }^{9}$ Local governments, while following the examples of many successful promotional campaigns in the world, should use the services of specialized marketing companies. At present, these activities are of a non-cohesive nature. "Everybody" (including Marshal's Offices, District Authority Offices, communes, tourism industry, local tourism organizations, associations, unions etc.) deal with these activities. Specialized companies should use the individual experience of institutions and organizations, part of which can boast of considerable achievements in this area. However, it should be emphasized that campaigns of this type are very expensive.

The situation presented above means that promotional activities in Poland are realized by too many institutions. To a significant extent, this causes their dispersion and duplication. Therefore, Polish tourism promotion can be referred to as "institutional promotion", yet in a negative context. Due to the lack of coordinated activities, very frequently the realized promotion does not bring about the expected results. This is true both of activities undertaken in the spatial dimension (settlement units, communes, regions etc.) and in the institutional dimension (local governments, tourist companies, organizations etc.).

It needs to be emphasized, however, that, according to the Polish Tourism Organization, this situation is undergoing a gradual change. The coordinated cooperation between entities involved in the promotion of Poland abroad and the formation of the tourism management system in Poland is gaining in significance for the implementation of individual objectives by the Polish Tourism Organization. The result of this cooperation is the added value generated from the synergy of activities and their increased effectiveness. The partners of the Polish Tourism Organizations at home include regional tourism organizations and local tourism organizations, local government entities and their partners as well as those entities that represent tourism industry, including the following: economic local governments, tourism industry organizations, the Forum of Incoming Tourism, the Forum of Tourist Information, the Forum of Cities, the Union of Rural Communes, the Union of Provinces, the Association of Polish Skiing and Tourist Stations, the Association of Underground Tourist Routes in Poland, the Union of Sea Communes and Towns, Municipal Convention Bureaux, the Association of Congresses and Conferences in Poland as well as industry associations in the area of business tourism and Product Consortiums. ${ }^{10}$

${ }^{9}$ A. Szwichtenberg, Gospodarka turystyczna polskiego wybrzeża, Monografia Wydziału Ekonomii i Zarządzania nr 121, Politechnika Koszalińska, Koszalin 2006, p. 174.

10 Plan działania na lata 2012-2013, Polska Organizacja Turystyczna, Warszawa 2012, p. 53. 


\section{Analysis of the tourism promotion system in France}

The institutionalism of the use of tourism promotion may nevertheless be of a positive nature. The so-called institutional tourism promotion system in France is an example of a model tourism promotion system, one which has been excellently functioning for many years now. ${ }^{11} \mathrm{~A}$ transfer of such a model to the realities of our state could bring only benefits to the Polish tourism. The fact that France held the first position in the world tourist ranking for many years as regards the number of tourist arrivals serves to demonstrate its effectiveness. For example, in 2012, France was visited by 83 millions of tourists, which accounted for c.a. $8.1 \%$ of all tourist arrivals in the world. ${ }^{12}$ The reasons of such a great success are to be sought in the tourism promotion system that has been efficiently functioning for over 30 years now.

In the economy of France, tourism is of an essential significance. It constitutes one of the most important developmental branches. This is also reflected in the considerably extended administrative structures of the entities responsible for the form of the French tourism.

In France, in 1982, an administrative reform had been implemented. Apart from the existing departments and communes, the third level of territorial community: the region, was introduced. Competences were assigned to the state, regions, departments and communes with regard to tourism and the objectives that followed from these competences were realized in close cooperation and in a coordinated manner. Promotional activities in France are now based on all of the above mentioned levels of administration. As mentioned previously, this is referred to as "institutional promotion." However, in contrast to Poland, every French town, department or region perceives a significant source of income in tourism. Therefore, they are very willing to cooperate with the aim of developing tourism. All the levels of administration have corresponding structures of tourism promotion.

Considering its structure (the administrative criterion), the tourism promotion system in France does not considerably differ from the one that is currently functioning in Poland (cf. Table 1). However, it should be emphasized that this concerns only those structures of tourism organizations (the Polish Tourism Organization, Regional Tourism Organizations and Local Tourism Organizations) that exist in Poland, i.e. only part of those entities that undertake promotional activities in tourism. The actual promotional activity looks different, however.

Two institution types, i.e. tourist offices (Office de Tourisme) and initiative syndicates (Syndicat d' Initiative) function on the lowest state administration level in France. They work in close cooperation with commune administrations. They generally pursue the same objectives. The difference in their names is related only to their sizes. Tourist offices are categorized in the four-star range depending on their sizes and effects achieved, opening times within the year and the level of services provided etc.

\footnotetext{
11 J. Sikorska, System promocji turystyki we Francji, „Rynek Turystyczny” 1994, No. 8, p. 16.

12 Tourism Highlights 2013 Edition, World Tourism Organization, Madrid 2013.
} 
Table 1. Systems of tourism promotion in France and in Poland according to the administrative criterion

\begin{tabular}{cllll}
\hline \multirow{2}{*}{ No. } & \multicolumn{3}{c}{ Institutions responsible for tourism promotion on the individual levels of administration } \\
\cline { 2 - 5 } & \multicolumn{2}{c}{ France } & \multicolumn{1}{c}{ Poland } \\
\hline 1. & State & $\begin{array}{l}\text { ATOUT FRANCE French Agency of Tourism } \\
\text { Development }\end{array}$ & State & $\begin{array}{l}\text { National Tourism Organization - Polish Tourism } \\
\text { Organization }\end{array}$ \\
\hline 2. & Region & regional tourism committees & Province & regional tourism organizations \\
\hline 3. & Department & departmental tourism committees & District & local tourism organizations \\
\hline 4. & Commune & - tourist offices & Commune & local tourism organizations \\
\hline
\end{tabular}

Source: M. Marczak, M. Boguszewicz-Kreft, Promocja usług, CeDeWu, Warszawa 2015, p. 141.

The main objectives of tourist offices and initiative syndicates include tourist services and tourist information, development of tourism products, promotion of destinations, operation of tourist facilities, organization of leisure activities and special events, coordination of the operations of various entities aimed at the development of local tourism.

Tourist offices and initiative syndicates are completely professional and are managed in the same way as real companies. In their organizational structure, there is a growing importance of staffing of positions connected with marketing and with promotion in particular. Hostesses, guides, promotion specialists and administrative personnel are hired. The directors of these offices mainly possess high qualifications in the area of tourism, management and economics. The statute of these institutions does not allow any profit-oriented business activity. Their profits are derived from three principal sources: member contributions (hotel owners, restaurant owners etc.), subsidies granted by communes and other institutions (chambers of commerce, savings banks), sale of postcards, posters, regional promotional materials, organization of guided tours etc.

The so-called departmental committees of tourism (Comite Depatrementale de Tourisme) operate on the level of the French department. They cooperate with general councils. It needs to be emphasized that out of 100 French departments, 98 departmental committees of tourism have been functioning since as early as 1960s! This is an intermediate level between the communal office or the initiative syndicate and the regional committee of tourism. They are financed with the budget of the general (departmental) council. Their legal status is the same as the status of tourist offices that operate on the commune's level. Departmental committees of tourism that operate in one region are in close cooperation with each other. The majority of them employ from 6 to 7 persons. To work for them, one needs to possess a diploma in the area of tourism, i.e. BTS (Brevet de Technicien Superieur) - an equivalent of the Polish diploma of a post-graduate school or a secondary school of hotel administration.

The regional committees of tourism deal with promotion on the regional level. They cooperate with the councils of regions. As in the case of tourist offices, initiative syndicates or departmental committees of tourism, their size depends on the nature of tourism in a particular area and the region's rank. The average number of personnel in regional committees of tourism is c.a. 8-9. Regional committees of tourism are financed by regional councils. Regardless of the size, the activity of each regional committee of tourism covers the same forms of activity, i.e.: 
- publication of brochures and other promotional materials,

- economic and commercial analyses of regional tourism products,

- consultancy in the area of education and professional in-service training in the region.

The education areas of their personnel involve various fields including tourism, arts history, management, economics, geography and spatial planning. Many of those employed by regional committees of tourism possess second- and third degree university diplomas (Bachelor or Master's degree). Regional committees of tourism have been members of the national federation of regional committees of tourism since 1987.

All of the above mentioned entities operating on communal, departmental and regional levels cooperated with Maison de la France (MDLF) established in 1987. This organization functioned within the structure of the ministry of tourism affairs, and its main objective was the tourism promotion of France, chiefly abroad. Maison de la France was an example of a significant participation of the private sector in tourism. For example, the share of private funds in financing the promotional budget of this National Tourism Organization in the year 1987 was $28.00 \%$, while in 1997 it amounted to $51.00 \%$. In the same period, public funds allocated for the operations of Maison de la France increased by $14.30 \%$, while private funds - by $200.00 \%$. In the same year, the distribution of the financing sources of Maison de la France was as follows: the state budget: $46.00 \%$, the private sector: $54.00 \%$.

In 2009, Maison de la France evolved into ATOUT FRANCE, i.e. the French Agency of Tourism Development (formed as a result of the merger of Maison de la France and ODIT France, i.e. an agency that dealt with tourism engineering in France, tourism development, analyzes, classification and standardization). The competencies of the new agency cover the functions previously performed by Maison de la France and ODIT France, i.e. supervision over the quality of tourist services in the country and the promotion of destinations outside of the borders of France. Apart from this, on the international arena, the sphere was developed of analyzes, studies and trainings addressed to the foreign representatives of tourism industry. ${ }^{13}$ ATOUT FRANCE functions on the basis of public and private partnership. This cooperation has been successfully practiced in France by these agencies since 1980s.

Referring to the tourism promotion system in Poland, one may attempt at making a comparison between the two institutional national tourism promotion systems (cf. Table 2).

The conducted analysis has demonstrated significant differences in the approaches to the issues of the promotion of tourist services in both countries. They concern chiefly the following:

- cooperation of local governments with the private sector (especially financing of promotion budgets),

- coordination of activities undertaken and involvement in the promotional process,

- appropriately selected and qualified personnel responsible for the realization of promotional activities.

${ }^{13}$ ATOUT FRANCE: www.atout-france.fr. 
Table 2. Comparison of tourism promotion systems in Poland and in France

\begin{tabular}{cll}
\hline No. & \multicolumn{1}{c}{ Properties of tourism promotion system } \\
\hline 1. & $\begin{array}{l}\text { Transparent structure of institutions responsible for tourism } \\
\text { promotion both at home and abroad }\end{array}$ & $\begin{array}{l}\text { Promotion conducted by too many institutions. This causes } \\
\text { a dispersion of activities and consequently, there are } \\
\text { no expected results }\end{array}$ \\
\hline 2. & $\begin{array}{l}\text { Close cooperation of local governments with tourism } \\
\text { industry (significant share of private sector in the financing } \\
\text { of promotional activities) }\end{array}$ & $\begin{array}{l}\text { Limited cooperation between the local-government entities } \\
\text { and the private sector (especially as regards the co-financing } \\
\text { of promotional budgets) }\end{array}$ \\
\hline 3. & $\begin{array}{l}\text { Cohesion and coordination of undertakings in the area } \\
\text { of tourism promotion }\end{array}$ & $\begin{array}{l}\text { No coordination, overlapping of promotional activities } \\
\text { by the various entities associated with tourism }\end{array}$ \\
\hline 4. & $\begin{array}{l}\text { Entities responsible for tourism promotion are managed } \\
\text { in the same manner as professional tourism companies }\end{array}$ & $\begin{array}{l}\text { Frequently, entities that serve other purposes (e.g. various } \\
\text { tourism unions and associations) deal with tourism promotion }\end{array}$ \\
\hline 5. & $\begin{array}{l}\text { Requirement of hiring highly qualified personnel to deal } \\
\text { with tourism promotion (e.g. diplomas in the area of tourism, } \\
\text { management, marketing an economics are required) }\end{array}$ & $\begin{array}{l}\text { No appropriately prepared and qualified personnel to be } \\
\text { in charge of promotion }\end{array}$ \\
\hline $\begin{array}{l}\text { 6. } \\
\text { Appropriate numbers of those who deal with tourism } \\
\text { marketing (including promotion) on individual administrative } \\
\text { levels (e.g. departmental committees of tourism: an average } \\
\text { of 6-7 people; regional committees of tourism: an average } \\
\text { of 8-9 people) }\end{array}$ & $\begin{array}{l}\text { Low numbers of those who directly deal with tourism } \\
\text { (including tourism promotion) in local government entities }\end{array}$ \\
\hline $\begin{array}{l}\text { Close cooperation between entities that deal with promotion } \\
\text { on all the administrative levels and cooperation with ATOUT } \\
\text { FRANCE }\end{array}$ & $\begin{array}{l}\text { Competition, no cooperation or exchange of experience } \\
\text { in the scope of tourism promotion on the individual levels } \\
\text { of local government administration }\end{array}$ \\
\hline
\end{tabular}

Source: M. Marczak, M. Boguszewicz-Kreft, Promocja ustug, CeDeWu, Warszawa 2015, p. 144.

\section{Conclusions}

The analysis presented in the article has demonstrated significant differences in the functioning of tourism promotion systems in Poland and France. In spite of many similarities concerning, in particular, the structure of both systems - which is closely related to the administrative system of both states as well as the institutional nature of promotion realized - many distinct features can be observed that have an impact on the effectiveness of promotional activities. It should be emphasized that these dissimilarities are determined by many factors, including the fact that the tourism promotion system in France has been functioning in a similar form for over 30 years now. This has allowed for the effective mechanisms of cooperation to develop between institutions responsible for tourism promotion on different levels of administration. Many economic initiatives undertaken in the French tourism sector have been realized based on the public and private partnership. To a significant extent, this strengthened the degree of confidence between the partners. The mentality needs to be emphasized of the representatives of French local government authorities, which is manifested in the perception of tourism as one of the chief economic functions in the context of many towns and regions. Furthermore, professional preparation of the personnel that attends to the tourist is of a great importance in France. 
In the present article, attempts have been made to demonstrate that it is not the number of entities and institutions which are responsible for promotion that translates into the effectiveness of the promotion system but their mutual relations, level of confidence and multifaceted cooperation (and not competition!) that is undertaken with the aim of the development of the tourism function. It is the author's opinion that these properties are not characteristic of the Polish tourism promotion system as it is based to a significant degree on activities undertaken by too many entities and institutions. Their activities are very frequently dispersed, non-cohesive, they are not systematic and they are inconsistent. In spite of considerable funds allocated for promotion, there are no expected results in the form of a significant growth of the incoming tourist traffic.

\section{References}

Analysis of foreign markets 2010 based on reports from Polish Tourist Information Centres + China and India, Warsaw 2011.

ATOUT FRANCE: www.atout-france.fr.

Borzyszkowski J., Polityka turystyczna państwa, Politechnika Koszalińska, Koszalin 2005.

Marczak M., Boguszewicz-Kreft M., Promocja ustug, CeDeWu, Warszawa 2015.

Plan działania na lata 2012-2013, Polska Organizacja Turystyczna, Warszawa 2012.

Polska Organizacja Turystyczna, www.pot.gov.pl.

Ordinance by the Minister of Economy dated 28 April 2006 on Granting the Statute for the Polish Tourism Organization amended with the Ordinance by the Minister of Economy dated 1 June 2007 on Granting the Statute for the Polish Tourism Organization.

Sikorska J., System promocji turystyki we Francji, „Rynek Turystyczny” 1994, No. 8.

Szwichtenberg A., Gospodarka turystyczna polskiego wybrzeża, Monografia Wydziału Ekonomii i Zarządzania nr 121, Politechnika Koszalińska, Koszalin 2006.

Tourism Highlights 2013 Edition, World Tourism Organization, Madrid 2013.

Act of 25 June 1999 on Polish Tourism Organization, "Journal of Laws" No. 62, Item 689. 


\section{ANALIZA SYSTEMU PROMOCJI TURYSTYKI W POLSCE NA TLE FRANCUSKIEGO MODELU „PROMOCJI INSTYTUCJONALNEJ”}

SŁOWA KLUCZOWE

STRESZCZENIE system promocji turystyki, promocja instytucjonalna, Narodowa Organizacja Turystyczna, skuteczność promocji

W artykule zaprezentowano analizę polskiego systemu promocji turystyki na tle modelowego według autora, rozwiązania francuskiego, opartego na tzw. ,promocji instytucjonalnej”. Zdecydowano się na dokonanie porównania tych systemów promocji turystyki z dwóch powodów. Po pierwsze, obydwa systemy promocji turystyki oparto na znacznej liczbie instytucji funkcjonujących zarówno na szczeblu lokalnym, jak i regionalnym, jednocześnie współpracujących z Narodową Organizacją Turystyczną. Po drugie, mimo potencjalnie widocznych podobieństw, analizowane systemy promocji wykazują wiele cech odmiennych, które w konsekwencji rzutują na wielkość i strukturę przyjazdowego ruchu turystycznego. W artykule przyjęto następującą tezę badawczą, iż skuteczny system promocji turystyki musi być oparty na wzajemnej współpracy wszystkich instytucji zaangażowanych w działania promocyjne. Dotyczy to podmiotów funkcjonujących na wszystkich szczeblach administracji (lokalny, regionalny, krajowy). 